Board of Governors of the Federal Reserve System

\author{
International Finance Discussion Papers
}

Number 608

April 1998

\title{
EL NIÑO AND WORLD PRIMARY COMMODITY PRICES: WARM WATER OR HOT AIR?
}

\author{
Allan D. Brunner
}

NOTE: International Finance Discussion Papers are preliminary materials circulated to stimulate discussion and critical comment. References in publications to International Finance Discussion Papers (other than an acknowledgement that the writer had access to unpublished material) should be cleared with the author or authors. Recent IFDPs are available on the Web at www.bog.frb.ged.us. 


\title{
El Niño and World Primary Commodity Prices: Warm Water or Hot Air?
}

\author{
Allan D. Brunner*
}

\begin{abstract}
This paper examines the historical effects of El Niño on world prices and economic activity. Although the primary focus is on world real non-oil primary commodity prices, the effects on G-7 consumer price inflation and GDP growth are also considered. This paper has several distinct advantages over previous studies. First, several econometric models are estimated using fairly broad measures of prices and economic activity. Second, the models include continuous measures of El Niño intensity (sea surface temperature and sea-level air pressure anomalies in the Pacific Ocean) rather than dummy variable measures. Finally, confidence intervals are constructed for all estimated effects of El Niño on world prices and economic activity.

The analysis indicates that El Niño has economically-important and statistically-significant effects on world real commodity prices. A one-standard-deviation surprise in El Niño, for example, raises real commodity price inflation about 3-1/2 to 4 percentage points. Moreover, El Niño appears to account for over 20 percent of commodity price inflation movements over the past several years. El Niño also has some explanatory power for world consumer price inflation and world economic activity, accounting for about 10 to 15 percent of movements in those variables.
\end{abstract}

Keywords: El Niño, commodity prices, business cycle fluctuations

* The author is an Economist in the Division of International Finance at the Board of Governors of the Federal Reserve System and can be reached by email at brunnera@frb.gov. The author thanks Neil Ericsson, Caroline Freund, Bill Helkie, Dave Howard, Karen Johnson, Andy Levin, and John Rosine for extensive comments on earlier versions of this paper. The author is responsible for any errors. The views expressed in this paper are solely the responsibility of the author and should not be interpreted as reflecting the views of the Board of Governors of the Federal Reserve System or of any other person associated with the Federal Reserve System. 


\section{Introduction}

This paper examines the historical effects of El Niño on world primary commodity prices, as well as other measures of world economic activity. Since its reappearance last spring, El Niño has intensified significantly and quite rapidly. By some measures, the current El Niño is the most severe episode in the past 100 years. The return of El Niño and its seeming severity have raised concerns about the possible consequences for economic activity in those countries that are likely to be affected (directly or indirectly) by El Niño.

There is, of course, an extensive literature devoted to estimating the effects of weather on economic activity. The bulk of this work concerns the effects of relatively high-frequency changes in weather on economic activity. While the effects of weather vary by geographic region and by industrial sector, ${ }^{1}$ a plethora of studies have documented the importance of precipitation and temperature to agricultural production, ${ }^{2}$ energy demand, ${ }^{3}$ and construction activity. ${ }^{4}$ In addition, Saunders (1993) found that Wall Street weather has a significant psychological effects on daily stock market returns.

There is also a great deal of interest in the effects of low-frequency weather developments on economic activity. Following Jevons (1884), a vast number of studies examined the relationship between sunspot cycles (ranging from 11-year to 100-year cycles) on atmospheric changes, on crop production, and on broader measures of economic activity. More recently, economists have turned their attention to the possible economic consequences of global warming -- see Mendelsohn et alia (1994), Cline (1996), and their cited references.

1 See Norrbin and Schlagenhauf (1988).

2 This literature dates back to at least Day (1965).

3 See Lawrence and Aigner (1979), EPRI (1981, 1983), Engle et al. (1986), and Maddala et al. (1997).

4 See, for example, Solomou and Wu (1997). 
Surprisingly, there has been little attention directed toward understanding the significance of medium-frequency weather fluctuations, such as El Niño events. Some of the notable exceptions are Handler (1983), Adams, et al. (1995), and Solow, et al. (1997). These studies are of only limited use, however, in understanding the importance of El Niño to the world economy. First, they focused on a small number of commodities and certain geographical areas thought to be significantly affected by El Niño. Consequently, one cannot conclude from those studies whether El Niño has any implications for broader measures of prices and economic activity. Second, none of these studies put confidence bounds on their calculated effects. As a result, it is difficult to draw any firm conclusions about the statistical importance of these phenomena for prices and economic activity. Finally, these studies used dummy variables to designate years in which there was unusual climactic activity. Thus, relatively weak El Niños were averaged with more severe episodes, likely biasing the estimated effects toward zero and toward insignificance.

This paper makes several important contributions to this literature. First, several simple econometric models are constructed to study the global economic consequences of El Niño. The primary focus of these models is on the effects on world real non-oil primary commodity prices, as measured by IMF commodity price indexes, although the effects on G-7 consumer price inflation and GDP growth are also considered. Second, the models include continuous measures of El Niño intensity (sea surface temperature and sea-level air pressure anomalies in the Pacific Ocean) rather than dummy variable measures. Finally, confidence intervals are constructed for all estimated effects of El Niño on world prices and economic activity.

The analysis indicates that El Niño has economically-important and statistically-significant effects on world commodity prices. A one standard-deviation surprise in El Niño, for example, raises real commodity price inflation about $3-1 / 2$ to 4 percentage points. Moreover, El Niño appears to account for over 20 percent of commodity price inflation movements over the past several years. El 
Niño also has some explanatory power for world consumer price inflation and world economic activity, accounting for about 10 to 15 percent of movements in those variables.

The remainder of this paper is organized as follows. Section II briefly reviews the general characteristics of El Niño events and describes the sea surface temperature and sea-level air pressure anomaly measures used in the econometric analysis. Section III constructs several econometric models and discusses the estimated effects of El Niño on commodity prices, world consumer price inflation, and world economic activity. Concluding remarks are provided in Section IV.

\section{What is El Niño?}

During "normal" seasons in the tropical Pacific, there is a persistent high pressure system located off the west coast of South America and a persistent low pressure system off the east coast of Australia. As a result, the prevailing surface winds in the tropical Pacific are "easterlies," blowing from east to west. These winds tend to push warm surface water from the eastern and central regions of the equatorial Pacific to the western regions (particularly to India, Indonesia, and Australia). In the eastern regions of the Pacific, cold, nutrient-rich water comes up from below to replace the displaced warmer water, leading to ideal living conditions for many cold-water tropical fish and providing an economic livelihood for the South American fishing industry. In the western regions of the Pacific, persistent oceanic heat and moisture cause frequent thunderstorms and some of the heaviest rainfall on earth.

Periodically, there is a shift in atmospheric pressures in the Pacific, as a low pressure system develops in eastern regions and a high pressure system develops in western regions. As a consequence, the prevailing easterly winds weaken and often become westerlies. In that case, warm surface water gets pushed toward South America and then spread north and south along the Pacific coasts of the Americas. The periodic shift in atmospheric pressure is called the Southern Oscillation, and the 
large-scale oceanic warming is known as El Niño. Together, El Niño and the Southern Oscillation (ENSO) have important, but erratic, influences not only on local weather patterns in the Pacific, but also on weather patterns across the globe and, therefore, on world economic activity. ${ }^{5}$

There are several ways to measure the intensity of an El Niño event. Two widely cited measures of an El Niño's severity are sea surface temperature (SST) anomalies -- deviations between sea surface temperatures in a given region and the region's historical average -- and Southern Oscillation Index (SOI) anomalies -- deviations between air pressure differentials in the South Pacific and their historical averages. ${ }^{6}$ SOI anomalies for the Pacific and SST anomalies for the so-called "Niño1+2" region (an eastern region of the Pacific just off the coasts of Ecuador and Peru) are illustrated in Figure 1. As the chart shows, the two measures are highly but not perfectly correlated. Indeed, the measures offer a somewhat different view of the current El Niño event. The SST anomaly measure reached an all-time high in late 1997, while the SOI anomaly measure is in line with previous episodes.

The chart also indicates that the time-series properties of El Niños are similar to those for business cycles. El Niños typically occur at three-to-seven year intervals and last about two years. They also vary greatly in their intensity. The most severe El Niño in recorded history (prior to the current event) occurred in 1982-83 and had devastating effects in many regions of the world. The most recent El Niño took place in 1994-95 and was relatively mild.

The experience of the 1982-83 El Niño highlights the possible consequences of a severe episode. That episode began in May of 1982, when easterly winds weakened and shifted to westerlies. As warm surface water accumulated off the Pacific coasts of the Americas, many tropical fish were

5 Although ENSO refers to the joint occurrence of El Niño and the Southern Oscillation, the terms ENSO and El Niño are often used interchangeably.

${ }^{6}$ Other measures of an El Niño's severity include sea-level air temperature and wind speed anomalies. 
killed and others were sent to colder regions, thus harming fishing industries (especially anchovy and sardine industries) from Chile to British Columbia.

In addition, the 1982-83 El Niño created important global atmospheric disturbances, as highaltitude jet stream winds were altered, affecting weather patterns in Asia, in North and South America, and as far away as Africa. Ecuador and Peru, for example, received about seven years worth of rain in four months, causing extensive flooding and the destruction of several cities. In contrast, India, Indonesia, Malaysia, and Australia suffered droughts and disastrous forest fires. Abnormal wind patterns steered typhoons toward Hawaii and Tahiti rather than toward the Asian continent. In the United States, winter storms battered southern California and caused widespread flooding across many of the southern states, while more northern states experienced unseasonably mild weather.

Figure 1 also shows that the current El Niño is rivaling the 1982-83 episode. Indeed, several events over the past several months -- extremely warm ocean currents in the equatorial Pacific that drove cold-water fish far north and far south; torrential rains and flooding in Peru, Ecuador, and Chile; droughts in Australia and in South and Southeast Asia; raging forest fires in Indonesia, and severe winter storms and flooding in the United States -- closely parallel events during the early stages of the 1982-83 El Niño. On the other hand, the 1997 typhoon season was relatively normal, and India and Australia received some timely rainfall that helped abate the effects of droughts in those regions. Thus, whether the current El Niño proves to be more intensive and more devastating than its 1982-83 predecessor remains to be seen.

\section{El Niño and World Commodity Prices}

There is a substantial meteorological literature that documents the effects of El Niño on worldwide climatic conditions (air temperatures, precipitation, and wind patterns). However, only a few economic studies have focused on the possible consequences of El Niño for world economic activity -- 
for world production, prices, and international trade -- despite the ample anecdotal evidence discussed in the previous section. This paper provides a important step in that direction by focusing on the link between El Niño and world commodity prices and, to a lesser extent, world inflation and economic activity.

Figure 2 charts the recent historical relationship between a measure of real commodity price inflation and two measures of El Niño intensity. The commodity price measure (the solid line in each panel) is derived using the IMF's index of non-oil primary commodity prices and the average CPI inflation rate for the G-7 countries. This measure is plotted against both SST anomalies (the upper panel) and SOI anomalies (the lower panel). There is a surprisingly close association between the El Niño index and commodity price changes, given the large array of other factors that are likely to affect commodity prices (for example, world economic activity). As can be seen in both panels of Figure 2, the 1982-83 El Niño had the most dramatic effect on commodity prices, although the 1972-73 and 1986-87 events were also important contributors to commodity price inflation in those years.

Much of the correlation between El Niño and commodity prices is accounted for by the food component of the overall index, although there is also weak evidence of a correlation between the El Niño index and agricultural raw material prices and metals prices. These results are roughly consistent with the anecdotal evidence discussed in the previous section. During the 1982-83 El Niño event, for example, grain and oilseed prices rose sharply in late 1982 and early 1983, both because of droughts in Asia and Australia and because of the displaced fish population (soybean meal is a close substitute for fishmeal). Supply disruptions in Southeast Asia (droughts) and South America (floods) also put some upward pressures on copper prices. Finally, cocoa and, to a lesser extent, coffee prices were pushed up due to dry conditions in Malaysia and Indonesia and due to excessive rainfall in South America.

Figure 3 charts the historical relationship between SOI anomalies and G-7 inflation and GDP 
growth rates. These relationships are not as tight as the relationship between measures of El Niño and world commodity prices. Nevertheless, the generally positive effects of El Niño on both inflation and economic growth can be seen following the largest El Niño events in 1972, 1982, and 1986.

\section{$\underline{\text { Statistical Models }}$}

In order to better gauge the effects of El Niño events on world prices and growth, a total of ten vector autoregressive (VAR) models were estimated. Each four-variable VAR model contained $\mathrm{ENSO}_{\mathrm{t}}$, a measure of ENSO intensity. $\mathrm{ENSO}_{\mathrm{t}}$ was either the SST anomaly or the SOI anomaly measure. Each model also included the average CPI inflation rate $\left(\pi_{t}^{g}\right)$ and the average GDP growth rate $\left(\Delta y_{t}\right)$ for the G-7 countries. Finally, each VAR contained one of five different measures of real commodity price inflation $\left(\pi_{t}^{c p}-\pi_{t}^{g}\right)$. The real commodity price inflation measures were based on the IMF's five index measures of non-oil primary commodity prices: i) foods, ii) beverages, iii) agricultural raw materials, iv) metals, and v) all non-oil commodities. ${ }^{7}$

The models were of the following form:

$$
\begin{aligned}
& \text { ENSO }_{t}=\mu_{s}+A_{11}(L) \text { ENSO }_{t-1}+\epsilon_{t} \\
& X_{t}=\phi_{S}+A_{21}(L) \text { ENSO }_{t}+A_{22}(L) X_{t-1}+\eta_{t}
\end{aligned}
$$

where

$$
\left[\begin{array}{l}
\epsilon_{t} \\
\eta_{t}
\end{array}\right] \sim N\left(\left[\begin{array}{l}
0 \\
0
\end{array}\right],\left[\begin{array}{ll}
\sigma_{\epsilon}^{2} & 0 \\
0 & \Sigma_{\eta}
\end{array}\right]\right)
$$

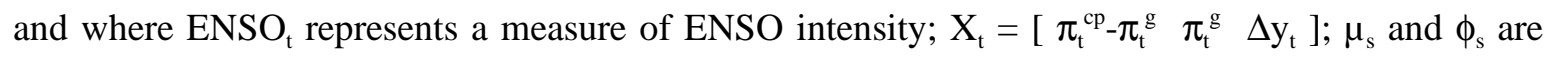
seasonally-varying constants; $A_{11}(L), A_{21}(L)$ and $A_{22}(L)$ are polynomials in $L$, the lag operator; $\varepsilon_{t}$ is a

\footnotetext{
7 All economic variables were constructed using the IMF's International Financial Statistics.
} 
exogenous shock to $\mathrm{ENSO}_{\mathrm{t}}$; and $\eta_{\mathrm{t}}$ is a $3 \mathrm{x} 1$ vector of innovations to $\mathrm{X}_{\mathrm{t}}$.

Several aspects of the specification in (1) and (2) deserve discussion. First, it seems reasonable that ENSO events are not influenced contemporaneously by economic events. Thus, ENSO $_{t}$ is assumed to affect $\mathrm{X}_{\mathrm{t}}$ contemporaneously but not vice versa. This assumption also identifies the ENSO shocks $\left(\varepsilon_{t}\right)$ as being orthogonal shocks; that is, $\varepsilon_{t}$ and $\eta_{t}$ are assumed to be uncorrelated. Second, the idea that ENSO events are strictly exogenous -- as shown in (1) -- is a testable hypothesis. Indeed, Wald tests revealed $\mathrm{ENSO}_{\mathrm{t}}$ is uncorrelated with lags of $\mathrm{X}_{\mathrm{t}}$ at conventional significance levels. Third, $\Sigma_{\eta}$ is expected to be non-diagonal; that is, the individual innovations within $\eta_{t}$ are correlated. However, since the focus of this analysis is entirely on the role of $\varepsilon_{t}$ (which is uncorrelated with $\eta_{t}$ ), it is not necessary to make any orthogonalizing assumptions about $\eta_{\mathrm{t}}$. Finally, it should be noted that the economic variables in (1) are expressed as first differences. Augmented Dickey-Fuller tests indicated that the ENSO measures are $\mathrm{I}(0)$, while the economic variables are $\mathrm{I}(1)$ in log levels and $\mathrm{I}(0)$ in first differences. Since there was no evidence of cointegration among the variables in log levels, the economic variables were expressed in first-difference form.

The ten VAR models were estimated using quarterly data from 1963 through 1997. Based on a sequence of general-to-specific likelihood ratio tests, it was determined that the appropriate lag length for all of the VARs is six quarterly lags. The estimated model coefficients showed some evidence of instability, mostly associated with the equations describing the evolution of consumer price inflation. This is not too surprising given the high and volatile inflation rates seen in the 1970s relative to the lower and fairly stable rates seen in the rest of the sample period (see Figure 3).

\section{Estimation Results}

Does El Niño have any explanatory power for the economic variables in the models? Table 1 presents the results of Granger causality tests for the importance of El Niño. The first column of the table denotes the commodity price measure used in the VAR model, while columns two and three 
represent different measures of El Niño intensity. Thus, each entry in columns 2 and 3 denotes the respective significance level of a $\chi^{2}$ test for whether $A_{21}(L)$ in equation (1) is statistically different from zero. There are a couple of aspects of the results in Table 1 worth noting. The SOI anomaly measure of El Niño intensity appears to have a much stronger statistical relationship with the economic variables than the SST anomaly measure does. This is true regardless of which commodity price measure is being used. On the other hand, the statistical significance of the SST measure is somewhat sensitive to the commodity price measure that is being included in the VAR model. In particular, the SST measure is statistically significant at the 5 percent level only when all primary commodity prices or when food commodity prices are included in the model. The statistical importance of the SST measure is weaker when prices of beverages, agricultural raw materials, or metals are included.

Figures $4 \mathrm{a}$ and $4 \mathrm{~b}$ report the impulse response functions associated with surprises in El Niño for two of the ten estimated models. The model illustrated by Figure 4a included SST anomalies, while the model shown in Figure $4 \mathrm{~b}$ contained the SOI measure. Both models contained the real commodity price inflation rate for all primary commodities, as well the average CPI inflation rate and GDP growth rate for the G-7 countries. The solid lines in the figures indicate the impulse responses for a one standard deviation surprise in the ENSO measure, while the dashed lines denote twostandard-deviation confidence intervals for each impulse response function.

As shown in the upper left panels of both figures, a surprise in El Niño is quite persistent, leading to raised sea surface temperatures and sea-level air pressure differentials (above their historical averages) for four subsequent quarters after the initial surprise. The upper right panels show that a one standard deviation El Niño surprise raises commodity price inflation (in real terms) an estimated 3-1/2 to 4 percentage points two quarters after the initial surprise. Commodity prices fall by a similar amount in the second and third years after the initial surprise. A similar pattern is evident for other measures of commodity prices (not shown). Not surprisingly, prices for food commodities and 
agricultural raw materials are affected the most by El Niño, although prices of beverages and metals are also pushed up and then down, especially when the SOI anomalies are used as the measure of El Niño intensity.

The lower left panels of Figure 4 indicate that El Niño has a similar "up-then-down" effect on overall prices among the G-7 countries, although the effect is much weaker and only marginally significant from zero for SOI measure. This relatively subdued influence on overall consumer prices is not unexpected since primary commodities account for only a fraction of overall finished good costs. Finally, as shown in the lower right panels, economic activity in the G-7 countries appears to be stimulated by an El Niño event -- raising GDP growth as much as one-half of a percentage point. Again, these effects are somewhat sensitive the ENSO measure used: The effects are statistically significant at the 5 percent level for the SST measure; they are significant at only the 10 percent level for the SOI measure. The stimulatory effects of El Niño on G-7 economic activity is somewhat surprising. One possible explanation for this result is that there is a measurable increase in investment spending (especially residential construction) following wind storms and flooding that are often associated with El Niño in some countries. On the other hand, this result could be capturing increased aggregate demand from other countries (for food, housing materials, machinery, equipment, etc) that are devastated by El Niño. In any case, this possible relationship deserves further investigation.

While the Granger causality tests and the impulse response functions point to a strong statistical relationship between El Niño and world commodity prices and, to a lesser extent, to a statistically-significant relationship between El Niño and world inflation and economic activity, they provide no indication of economic significance. Tables $2 \mathrm{a}$ and $2 \mathrm{~b}$ and Figures $5 \mathrm{a}$ and $5 \mathrm{~b}$ provide evidence that El Niño has substantial economic importance. Each of the ten estimated VARs was used to calculate k-step-ahead dynamic forecasts for real commodity price inflation, world CPI inflation and world economic activity for each time period in the data sample. The resulting forecast errors were 
then decomposed into the portion attributable to El Niño $\left(\varepsilon_{t}\right)$ and the portion attributable to all other factors $\left(\eta_{t}\right)$. The variances of these forecast errors were also decomposed in a similar manner. ${ }^{8}$

The results of the variance decomposition exercise for four- and sixteen-quarter-ahead forecasts are presented in Tables $2 \mathrm{a}$ and $2 \mathrm{~b}$. Table $2 \mathrm{a}$ shows the results when SST anomalies are used to capture El Niño intensity, while Table 2b illustrates the results for SOI anomalies. The results can be summarized as follows. First, El Niño appears to account for a substantial amount of variation in the economic variables, regardless of which measure of El Niño is used, although the SOI anomalies generally have a stronger and more statistically-significant influence. Second, in the short run, El Niño's influence is mostly on food prices, accounting over 14 percent of the four-quarter-ahead forecast error variance in these prices. El Niño appears to have little effect on world inflation, and the two El Niño measures provide conflicting information about the short-run effects on economic activity.

Third, El Niño's influence is much stronger over the longer horizon, accounting for over 20 percent of the variation in real primary commodity prices and about 14 percent of the variation in G-7 economic activity. The results for commodity prices are quite consistent with the anecdotal evidence discussed in Section II: Most of the effects on commodity prices are attributable to El Niño's effects on food and agricultural raw material prices, although metals prices are also moved around a bit by both El Niño measures. In contrast, the measures provide conflicting precision regarding the effects on beverage prices and on the average CPI inflation rate among G-7 countries.

Finally, Figures $5 \mathrm{a}$ and $5 \mathrm{~b}$ present the historical decomposition of the forecast errors for the three economic variables with respect to SST and SOI anomalies, respectively. The results are consistent with the previous ones. The upper panels show that most of the estimated effects of El Niño on commodity prices are associated with the 1982-83 and 1986-87 El Niño events. Although El

8 The only assumption required to calculate these decompositions is that El Niño is weakly (contemporaneously) exogenous with respect to the other three variables in the VAR. As discussed previously, however, this paper models El Niño as strictly exogenous. 
Niño likely had important effects on commodity prices during the 1970s, these effects were overwhelmed by other factors, such as the oil price shocks and subsequent goods price inflation. The lower panels in both figures indicate that, although El Niño has had some influence on overall price inflation and economic activity in the past couple of decades, that influence is not as economically and statistically important as its influence on commodity prices.

\section{Conclusion}

This paper examined the historical effects of El Niño on world prices and world economic activity. The primary focus was on world real non-oil primary commodity prices, although the effects on G-7 consumer price inflation and GNP growth were also considered. This paper has several distinct advantages over previous studies. First, econometric models were estimated using fairly broad measures of economic activity. Second, the models included continuous measures of El Niño intensity (sea surface temperature and sea-level air pressure anomalies in the Pacific Ocean) rather than dummy variable measures. Finally, confidence intervals were constructed for all estimated effects of El Niño on world prices and economic activity.

The analysis indicate that El Niño has a economically-important and statistically-significant effect on world real commodity prices. A one standard-deviation surprise in El Niño, for example, raises commodity price inflation about 3-1/2 to 4 percentage points. Moreover, El Niño appears to account for over 20 percent of real commodity price inflation movements over the past several years. El Niño also has some explanatory power for world consumer price inflation and world economic activity, accounting for about 10 to 15 percent of movements in those variables. 


\section{REFERENCES}

Adams, Richard M., Kelly J. Bryant, Bruce A. McCarl, David Legler, James O’Brien, Andrew Solow, and Rodney Weiher (1995), "Value of Improved Long-Range Weather Information," Contemporary Economic Policy, 13:10-19.

Cline, William R. (1996), "The Impact of Global Warming on Agriculture: Comment" The American Economic Review, 86:1309-11.

Day, R.H. (1965), "Probability Distributions of Field Crops," Journal of Farm Economics, 47:713-43.

Engle, Robert F., C.W.J. Granger, John Rice, and Andrew Weiss (1986), "Semiparametric Estimates of the Relation between Weather and Electricity Sales," Journal of the American Statistical Association, 81:310-20.

Electric Power Research Institute (1981), "Regional Load-Curve Models: QUERI's Model Specification, Estimation and Validation," EA-1672, Palo Alto, CA.

$$
\text { (1983), "Weather Normalization of Electricity Sales," EA-3142, Palo Alto, CA. }
$$

Handler, Paul (1983), "Climatic Anomalies in the Tropical Pacific Ocean and Corn Yields in the United States," Science, 20:1155-6.

Jevons, W. Stanely (1884), "Commercial Crises and Sunspots" in Investigations in Currencies and Finance, edited by H.S. Foxwell, London:McMillan and Company, Ltd.

Lawrence, Anthony, and Dennis Aigner (1979), "Modelling and Forecasting Time-of-Day and Seasonal Electricity Demands," Journal of Econometrics, 9:xx-xx.

Maddala, G.S., Robert P. Trost, Hongyi Li, and Frederick Joutz (1997), "Estimation of Short-run and Long-run Elasticitities of Energy Demand from Panel Data Using Shrinkage Estimators," Journal of Business and Economic Statistics, 15:90-100.

Mendelsohn, Robert, William Nordhaus, and Daigee Shaw (1994), "The Impact of Global Warming on Agriculture: A Ricardian Analysis," The American Economic Review, 84:753-771.

Norrbin, Stefan C., and Don E. Schlagenhauf (1988), "An Inquiry Into the Sources of Macroeconomic Fluctuations," Journal of Monetary Economics, 22:43-70.

Saunders, Edward M. (1993), "Stock Prices and Wall Street Weather," The American Economic Review, 83:1337-1345.

Solomou, Solomos and Weike Wu (1997), "The Impact of Weather on the Construction Sector Output Variations, 1955-1989," DAE Working Papers, \#9722, University of Cambridge, Cambridge, UK. 
Solow, Andrew, Richard F. Adams, Kelly J. Bryant, David Legler, James O’Brien, Bruce A. McCarl, William Nayda, and Rodney Weiher (1997), "The Value of Improved ENSO Prediction to U.S. Agriculture," Climatic Change, forthcoming. 
Table 1. Granger Causality Tests for Importance of El Niño to World Economic Activity

$$
X_{t}=\phi_{s}+A_{21}(L) \text { ENSO }_{t}+A_{22}(L) X_{t-1}+\eta_{t}
$$

\begin{tabular}{|c|c|c|}
\hline \multirow[b]{2}{*}{ IMF Commodity Price Index } & \multicolumn{2}{|c|}{$\begin{array}{l}\text { Significance Level of } \chi^{2}(18) \text { Test } \\
\text { for } \mathrm{A}_{21}(\mathrm{~L})=0 \text { where: }\end{array}$} \\
\hline & $\mathrm{ENSO}_{\mathrm{t}}=\mathrm{SST}_{\mathrm{t}}$ & $\mathrm{ENSO}_{\mathrm{t}}=\mathrm{SOI}_{\mathrm{t}}$ \\
\hline All Primary Commodities & .02 & $<.01$ \\
\hline Food & .05 & $<.01$ \\
\hline Beverages & .13 & $<.01$ \\
\hline Ag. Raw Materials & .10 & $<.01$ \\
\hline Metals & .17 & $<.01$ \\
\hline
\end{tabular}


Table 2a. Contribution of El Niño to the Variances of the Economic Variables -- $\mathrm{ENSO}_{\mathrm{t}}=\mathrm{SST}_{\mathrm{t}}$ (standard errors are in parentheses, boldface indicates significance at 5\% level)

\begin{tabular}{|c|c|c|c|c|}
\hline \multirow[b]{2}{*}{ Economic Variable } & \multicolumn{4}{|c|}{$\begin{array}{c}\text { Percentage of K-step-ahead Forecast Error Variance } \\
\text { Attributable to El Niño }\end{array}$} \\
\hline & \multicolumn{2}{|c|}{$\mathrm{k}=4$} & \multicolumn{2}{|c|}{$\mathrm{k}=16$} \\
\hline \multicolumn{5}{|l|}{ Commodity Price Inflation } \\
\hline All Primary Commodities & 16.3 & $(6.7)$ & 22.0 & $(8.9)$ \\
\hline Food & 14.3 & (5.6) & 19.6 & $(6.8)$ \\
\hline Beverages & 3.8 & $(3.0)$ & 9.7 & $(5.0)$ \\
\hline Ag. Raw Materials & 8.1 & $(4.7)$ & 16.4 & (7.6) \\
\hline Metals & 9.1 & (5.1) & 13.7 & (6.3) \\
\hline CPI Inflation (G-7 countries) & 3.8 & $(2.6)$ & 9.0 & (4.9) \\
\hline GDP Growth (G-7 countries) & 11.0 & $(5.5)$ & 14.3 & $(6.1)$ \\
\hline
\end{tabular}


Table 2b. Contribution of El Niño to the Variances of the Economic Variables -- $\mathrm{ENSO}_{\mathrm{t}}=\mathrm{SOI}_{\mathrm{t}}$ (standard errors are in parentheses, boldface indicates significance at 5\% level)

\begin{tabular}{|c|c|c|c|c|}
\hline \multirow{3}{*}{$\begin{array}{l}\text { Economic Variable } \\
\text { Commodity Price Inflation }\end{array}$} & \multicolumn{4}{|c|}{$\begin{array}{c}\text { Percentage of K-step-ahead Forecast Error Variance } \\
\text { Attributable to El Niño }\end{array}$} \\
\hline & \multicolumn{2}{|c|}{$\mathrm{k}=4$} & \multicolumn{2}{|c|}{$\mathrm{k}=16$} \\
\hline & & & & \\
\hline All Primary Commodities & 11.3 & $(5.0)$ & 21.1 & $(8.1)$ \\
\hline Food & 14.7 & $(5.8)$ & 23.9 & $(7.7)$ \\
\hline Beverages & 4.7 & $(3.5)$ & 9.7 & $(4.6)$ \\
\hline Ag. Raw Materials & 8.0 & $(4.8)$ & 15.1 & $(6.9)$ \\
\hline Metals & 6.0 & $(4.2)$ & 14.9 & (6.7) \\
\hline CPI Inflation (G-7 countries) & 8.9 & $(4.6)$ & 19.0 & $(6.8)$ \\
\hline GDP Growth (G-7 countries) & 7.3 & $(3.8)$ & 14.3 & $(5.2)$ \\
\hline
\end{tabular}


Figure 1. Two Measures of ENSO Intensity

(standard deviations from historical averages)

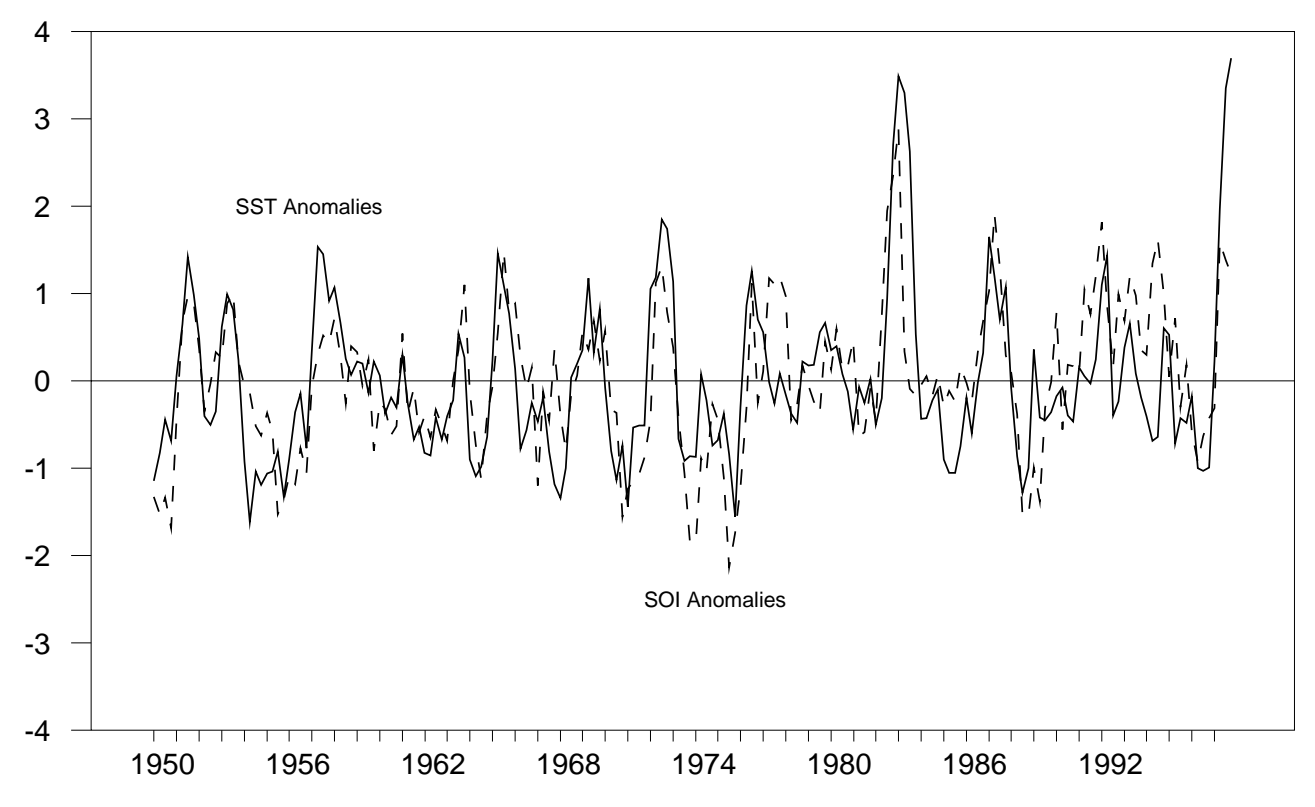


Figure 2. IMF Commodity Price Inflation and ENSO Measures
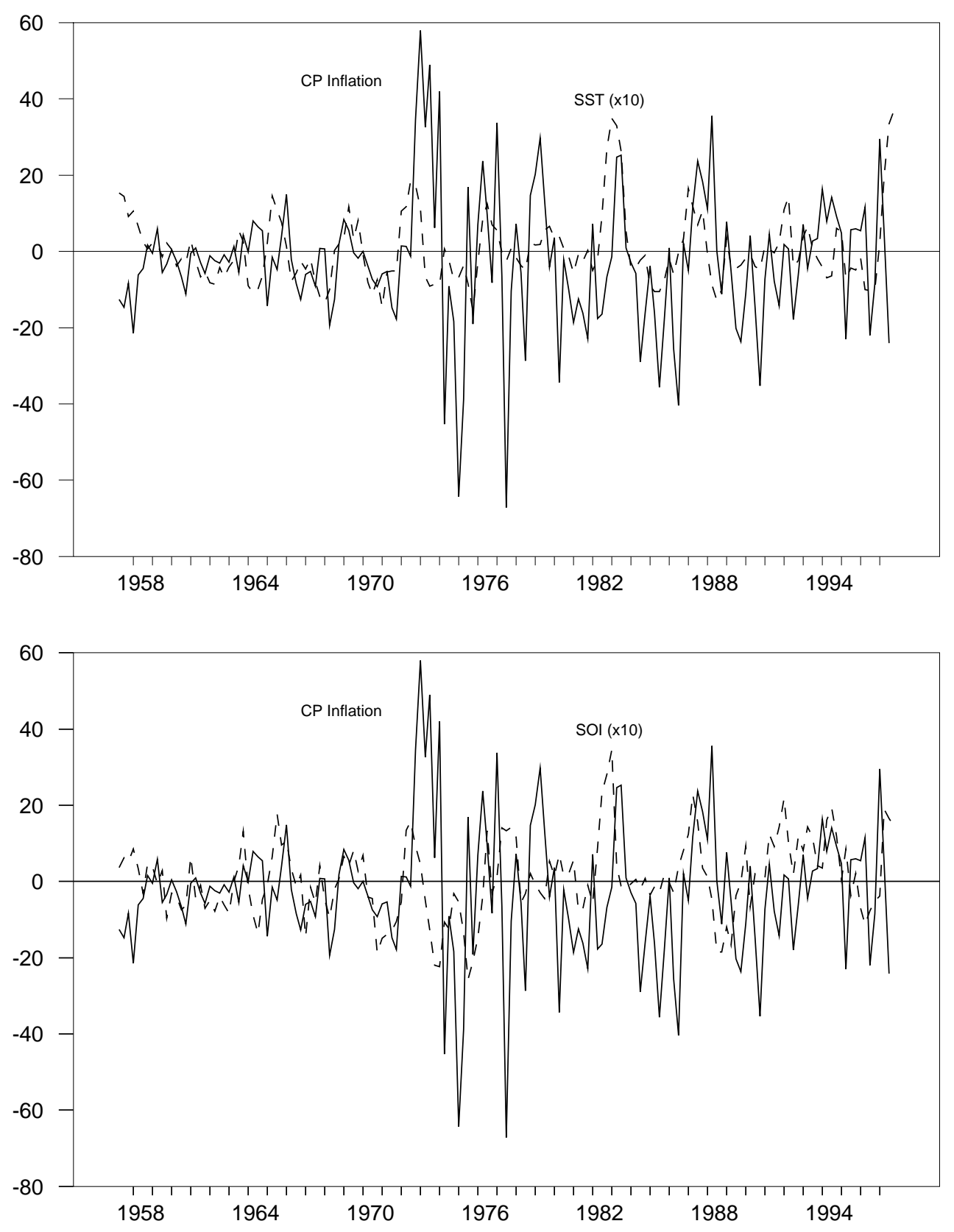
Figure 3. G7 Inflation and Economic Activity and SOI Anomalies
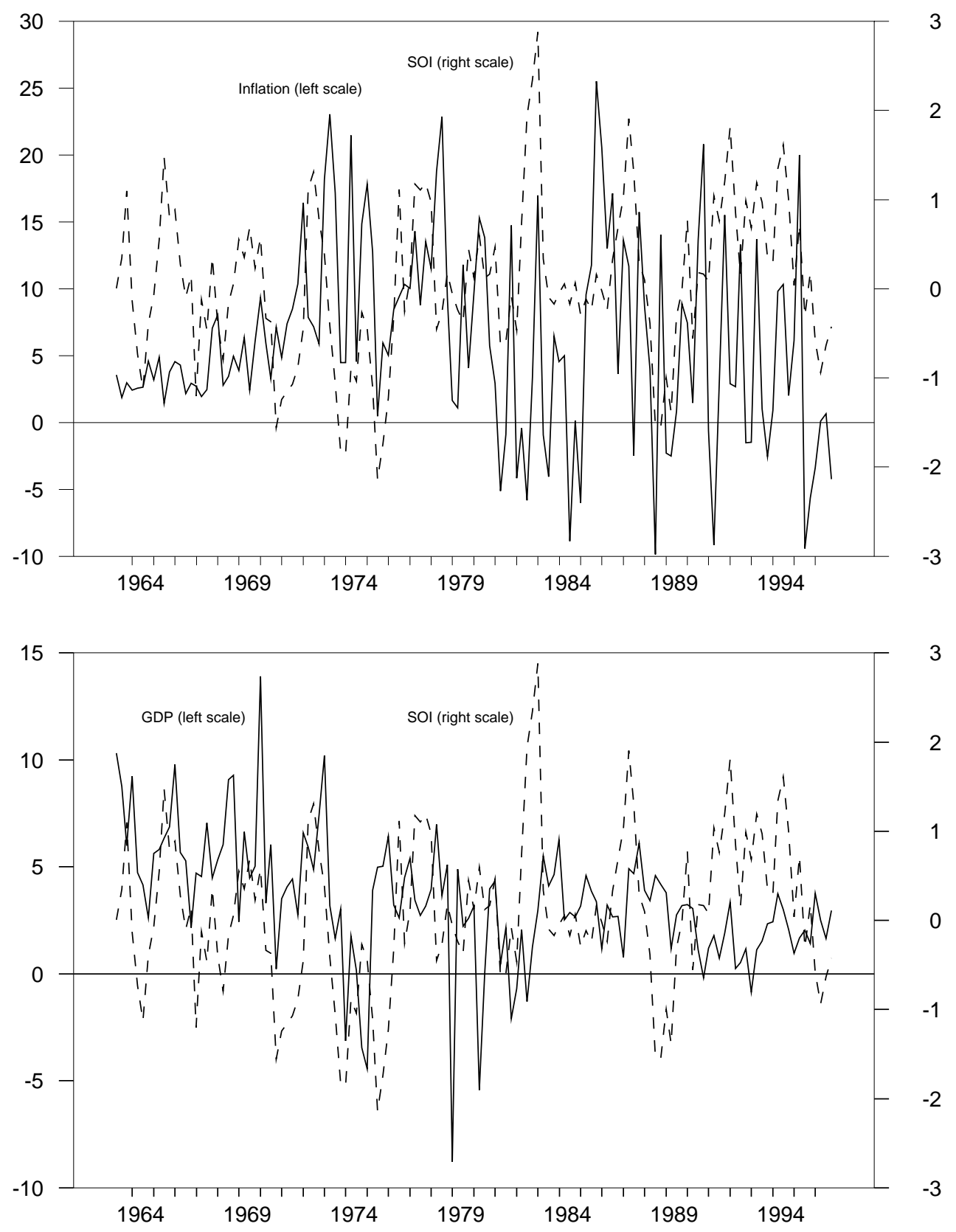
Figure 4a. The Effects of a Surprise in SST
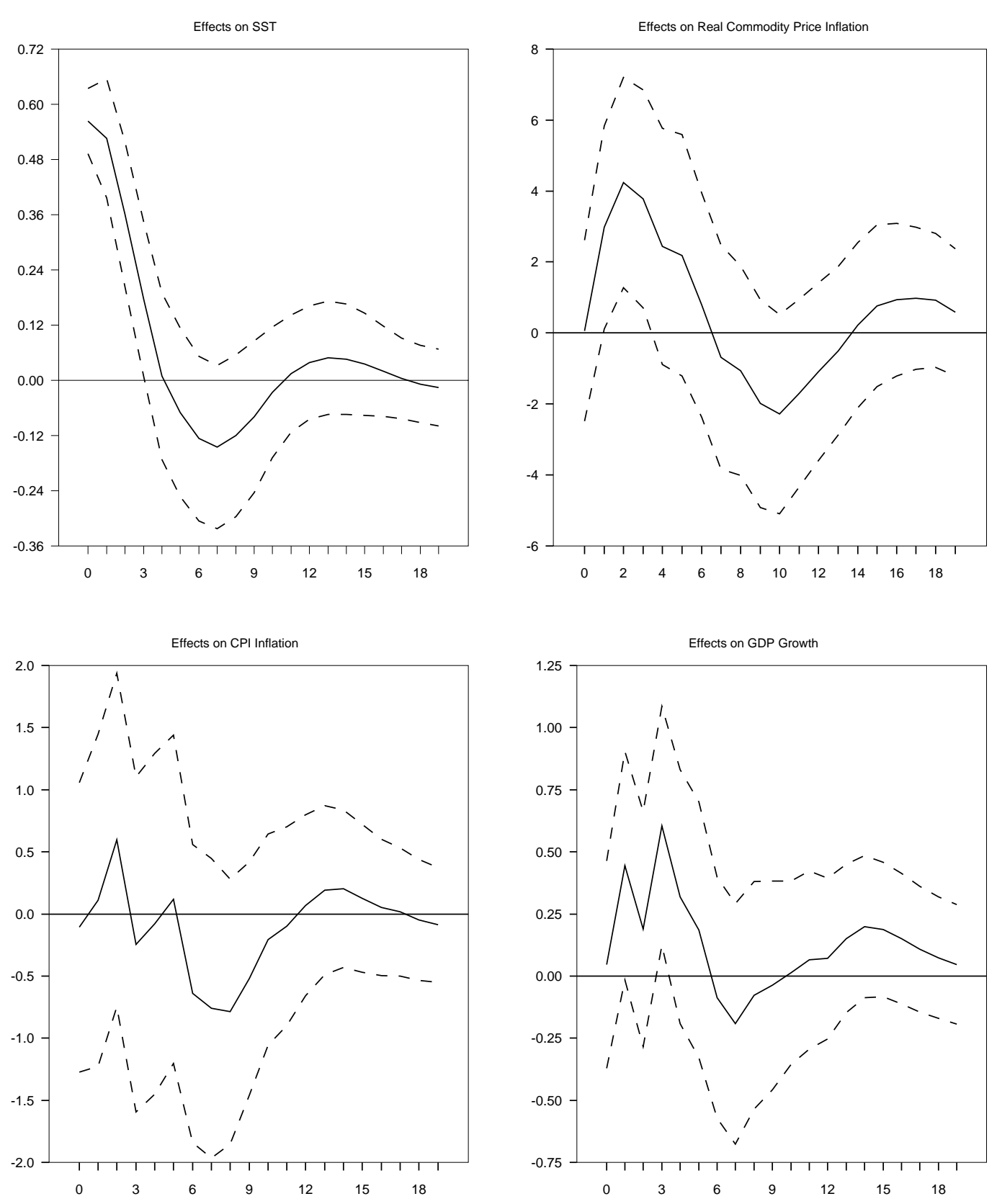
Figure 4b. The Effects of a Surprise in SOI
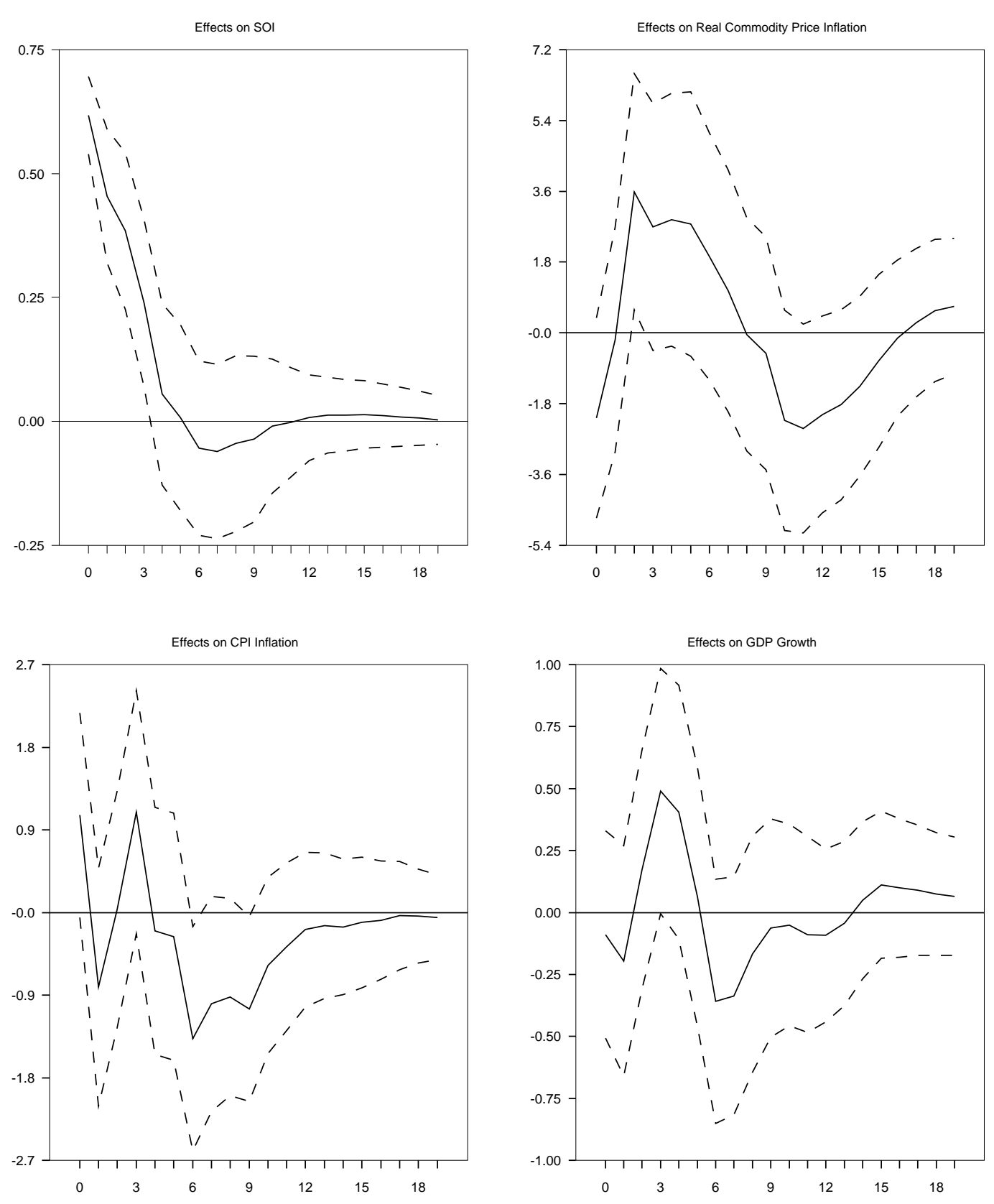
Figure 5a. The Historical Contributions of SST Anomalies
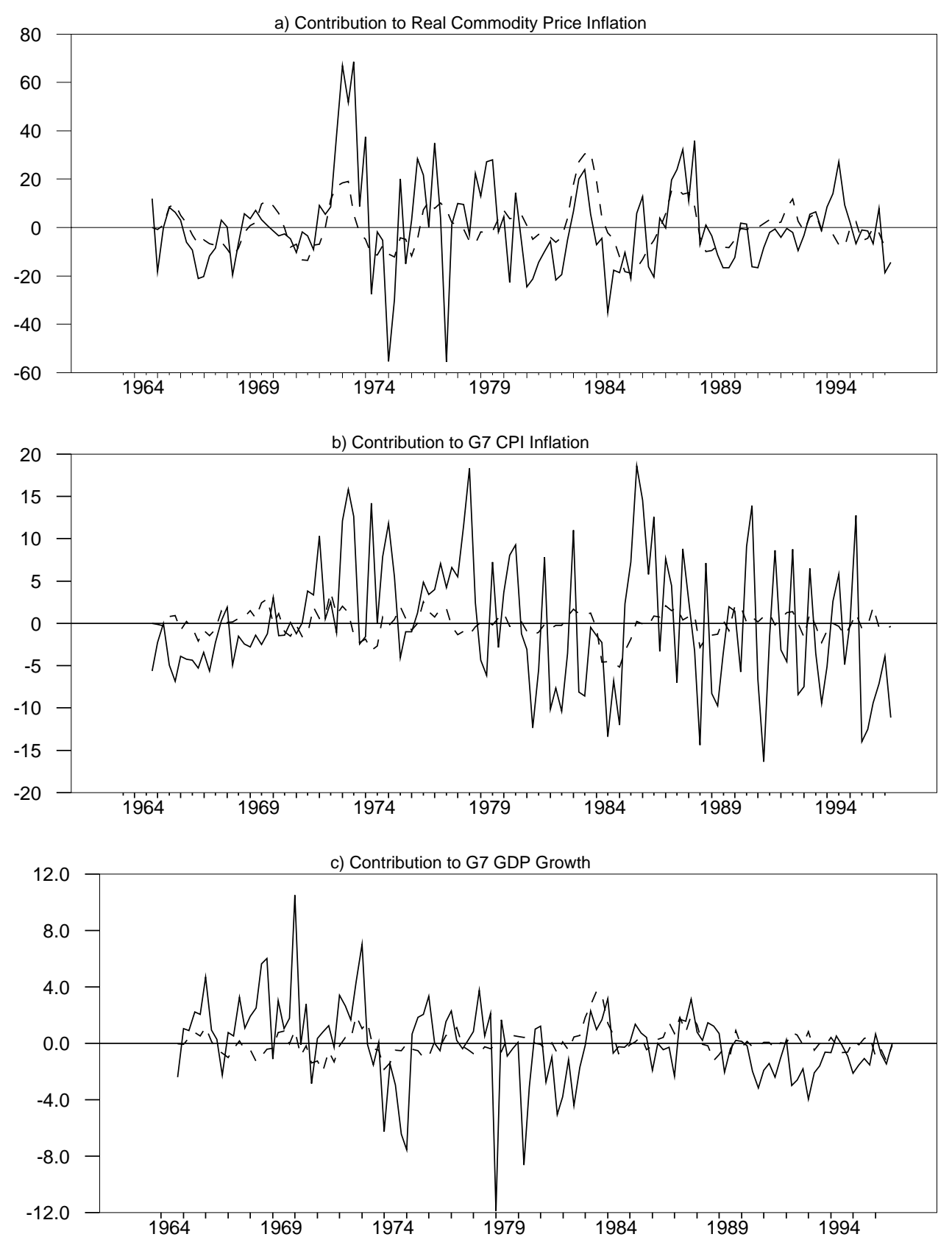
Figure 5b. The Historical Contributions of SOI Anomalies
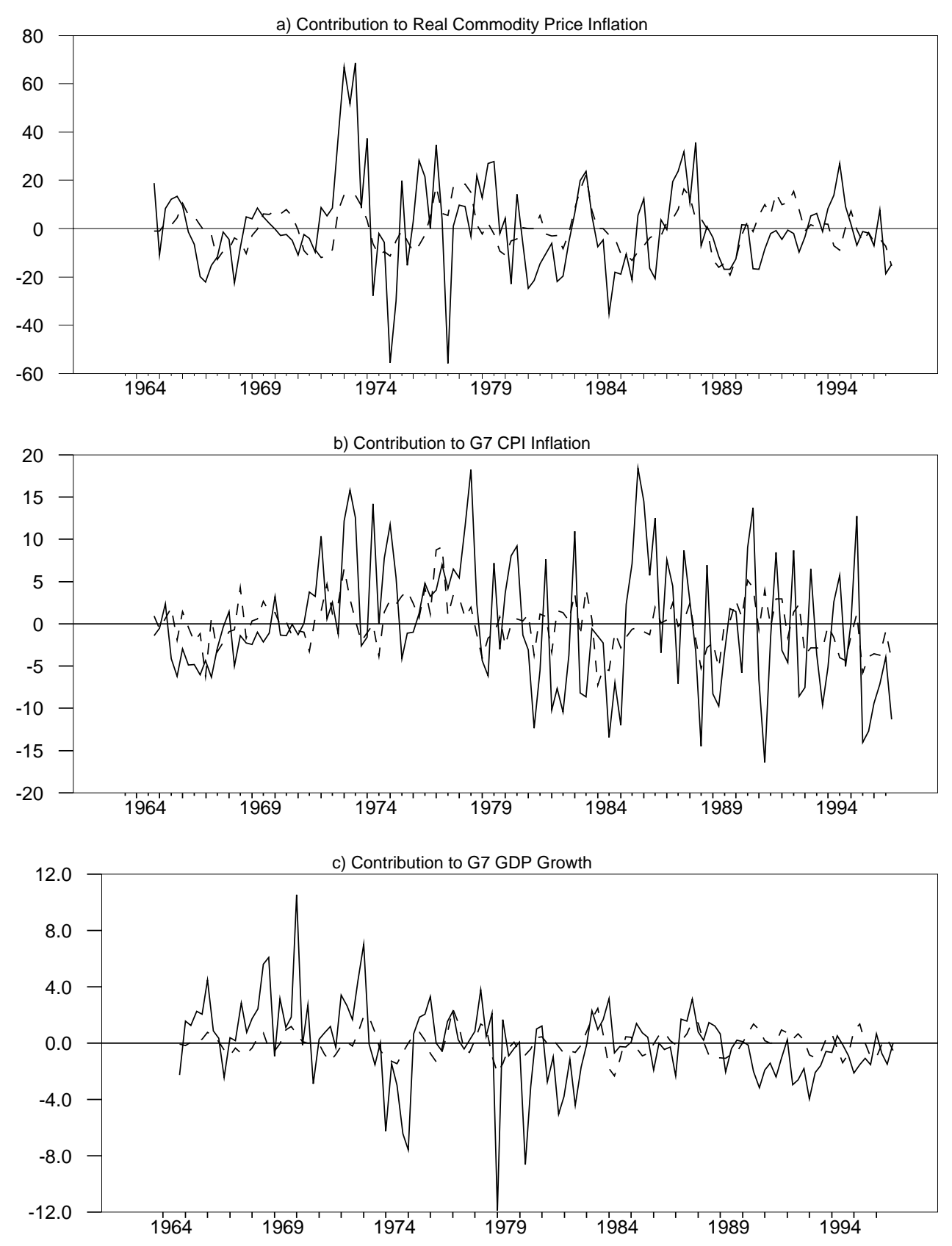